\title{
Conference applied natural sciences 2019
}

\section{J. Trögl ${ }^{1} \cdot$ I. Matušíková ${ }^{2}$}

Published online: 4 January 2021

(c) Islamic Azad University (IAU) 2021

Herein is a special issue of International Journal of Environmental Science and Technology (IJEST) devoted to 7th International Scientific Conference Applied Natural Sciences 2019 held on September 25-27, 2019, in Tále, Slovakia. Since its establishment in 2007 , the conference has been growing from local event to truly international event with participants from three continents and eleven countries in 2019. The traditional topics-chemistry, biology and biotechnology - have been extended by several exciting and modern research areas such as biomedical chemistry, environmental technology and applied informatics. Clearly, environmental issues strongly resonated and the conference appeared to provide a perfect platform for bringing together different scientific disciplines for seeking sustainable solutions.

What remained throughout the history of the conference is the dominant orientation on young scientists and Ph.D. students, many of which passed their first opportunity of presenting in English in front of the international audience. Thus, majority of the conference papers in this issue are authored by young perspective researchers. The papers are related to environmental chemistry, environmental technologies and biotechnologies, molecular biology studies of ecosystems, informatics and geoinformatics in environmental research and protection. The conference papers (ordered first and labeled) have undergone standard IJEST peer-review and were supplemented by other related standard submissions to the capacity of the issue.

On behalf of the organizers I would like to thank IJEST and especially the editor-in-chief Prof. Abbaspour for the possibility to publish this special issue. I would also like to invite the academic community to 8th Applied Natural Sciences conference, which will be held in Trnava, Slovakia, on September 22-24, 2021.

Josef Trögl, editor of the special issue.

J. Trögl

josef.trogl@ujep.cz

1 Faculty of Environment, Jan Evangelista Purkyně University in Ústí nad Labem, Pasteurova 3632/15, Ústí nad Labem, Czech Republic

2 Faculty of Natural Sciences, University of SS. Cyril and Methodius in Trnava, J. Herdu 2, 91701 Trnava, Slovakia 